JACK BURGERS EN HUGO VAN DER LUGT 'Zwarte vlucht' - De suburbanisatie van Surinamers uit Rotterdam 126

\section{HESTER DIBBITS}

Nieuw maar vertrouwd - Migranteninterieurs, sociale klasse en etniciteit $\quad \mid 43$

\section{SASKIA POLDERVAART}

Politisering van het dagelifks leven - De sociale politiek van de andersglobalistenbeweging 160

\section{RUUD STOKVIS}

De popularisering van het hardlopen $\quad 184$

IRENE COSTERA MEIJER EN MARJOLEIN VAN VOSSEN

Voorbeeldige televisie? - Moderne en postmoderne relatievertogen in hedendaags populair drama 202

\section{PAUL PENNINGS}

Wat mogen we verwachten van macrokwantitatief sociaal-wetenschappelijk onderzoek? 223

\section{BERNHARD KITTEL}

Enkele verduidelijkingen in het debat om de gekheid van een methodologie 226

Boekbesprekingen

229

\section{-}
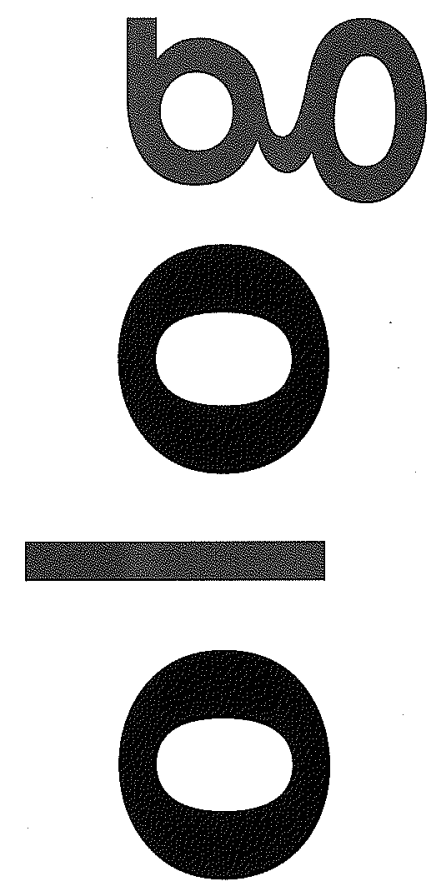

-

a
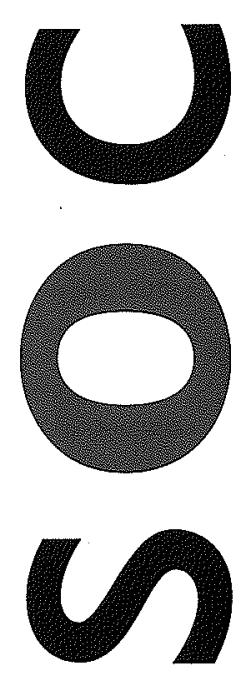
$\$ \quad$ Redactie

4 Stef Aupers, Jack Burgers, Jan-Willem Duyvendak, Dick Houtman, Bernard Kruithof, Giselinde Kuipers, Peter Mascini, Alex van Venrool (brekentredactent), Nico Wilterdink

\section{Redacteratit}

Christien Betnkgreve, Hans Boutellier, Godfried lingbersen, Valerte Pitssen, Rob yan Ginkel, Joha Gotdesblom, Marjolecin 't Hart, Johan Heilbron, Joame van der Leun, Henk Kleijer, Aafke Komter, Matily van de Port, Pat Schmabel, Ger Tillekens

\section{Bijdagen}

iliflragen en andere stukken voor de redactie

In tweevoud en op edorom zenden ain de

redactiesceretaris G. Kuipers, Erasmus Universiteit Rotterdam, Kunst en cultuurwetenschappen,

Postbus 1738, 3000 D R Rotterdam, e-mail:

kulpersog hkk,eur.n

Manuscripten worden anoniem beoordeeld door (de leden van) de kernredactie en externe beoordelatars. Door het toestemmen met publicatie in dit tijdschrift geeft de auteur tevens

toestemming voor elektronische openbaarmaking

\section{Boeken ter recensie}

Boeken ter recensie uitsluitend zenden aan de boekenredacteur Alex van Venrooij. Terugzending van ongevraagde recensie-exemplaren kan nie plaatsvinden. Voor het bespreken van nieuwe publicaties neme men contact op met de boekenredacteur (Erasmus Universiteit Rotterdam, Kunst- en cultuurwetenschappen, Postbus I738, 3000 DR Rotterdam, e-mail: vanvenrooij@fsw.eur.nl).

\section{Administratie}

Voor abonnementen richte men zich tot $d$ uitgever: Uitgeverij Boom (tijdschriften), Postbus 400, 7940 AK Meppel.

telefoon: 0522237555 , postgiro 2756509 . Sociologie verschijnt driemaandeliiks. De abonnementsprijzen bedragen: studenten en assistenten in opleiding (maximaal gedurende vie jaar) $€ 40,50$ (elektronisch) of $€$ 5 $\mathrm{x}_{\text {- }}$ (folio + elektronisch), niet-studenten $€ G_{\mathrm{I}}$, ( (elektronisch) of $€ 76$, (folio + elektronisch), niet-studenten buitenland $€ 76,5 \circ$ (elektronisch) of $€ 96$, , (folio + elektronisch), instellingen binnenland $€$ r 98 (folio + elektronisch), instellingen buitenland E229,- (folio + elektronisch).

\footnotetext{
Nectrturtitigeversuerbond

Groep uitgevers voo
}

Losse nummers: $E$ Ig- - (elektronisch). Leden van de Nederlandse Sociologische Vereniging ontvangen $\epsilon$ ro,- korting op een nieuw abonnement en $€ 5$, op een lopend abonnement (elektronisch of folio + elektronisch). Een abonnement geeft recht op I I $\mathrm{p}$-range of I e-mailadres.

Abonnementen kunnen wel tussentijds ingaan, maar niet tussentijds beëindigd worden

Opzeggingen ten minste één maand voor het einde van de jaargang. Indien men het abonnementsgeld gireert voor een ander (bijvoorbeeld zoon of dochter), gelieve men op het girostrookje duidelijk naam en adres van deze ander te vermelden, ter vermijding van dubbele incasso.

\section{Adverteren}

Voor opgave van advertenties: Uitgeverij Boom, Michiel Klaasen, telefoon: 0205200122 Advertentietarieven: $\mathrm{I} / \mathrm{I}$ pagina $€ 273,-$ $\mathrm{I} / 2$ pagina $€ 159$,

Cassette

Voor mensen met een leeshandicap verschijnt de volledige inhoud van Sociologie ook op cassette ingesproken. Inlichtingen: Centrum voor Gesproken Lektuur, Postbus 24, 5360 AA Grave, telefoon: 0468482345

On-line

Sociologie is als onderdeel van uw abonnement ook on line te raadplegen. Velen van $u$ hebben daarom al hun e-mailadres of (voor instellingen)

I P-adres(range) aan ons doorgegeven. Wilt u ook uw blad elektronisch bekijken en heeft $u$ uw e-mailadres nog niet aan ons doorgegeven, dan kunt u dat alsnog doen door:

- een e-mail te sturen naar

sociologie@uitgeverijboom.nl;

- een brief o.v.v. Sociologie te sturen naar Uitgeverij Boom, Prinsengracht 747-751, IOI7 IX Amsterdam;

- een fax o.v.v. Sociologie te sturen naar Uitgeverij Boom, 0206253327.

Wij verwerken uw e-mailadres in onze administratie. $U$ ontvangt daarna eenmalig uw password en username. Bij verschijning van ieder nieuw nummer van Sociologie ontvangt $u$ van ons een herinneringsmailtje met daarin een link naar het tijdschrift op internet.

Vormgeving omslag: Ewald Spieker Vormgeving binnenwerk: Hanneke Kossen

(3) Uitgeverij Boom, Amsterdam/Meppel. Niets uit dit tijdschrift mag worden verveelvoudigd en/of openbaar pernakikt zonder voorafgande schriftelike toestemming van de aitgever.

\section{INHOUD}

Sociologie, jaargang I $-2005 \mid 2$

Jack Burgers en Hugo van der Lugt

'Zwarte vlucht' - De suburbanisatie van Surinamers uit Rotterdam $\quad$ I26

Hester Dibbits

Nieuw maar vertrouwd - Migranteninterieurs, sociale klasse en etniciteit

Saskia Poldervaart

Politisering van het dagelijks leven - De sociale politiek van de

andersglobalistenbeweging $\mathrm{I} 60$

Ruud Stokvis

De popularisering van het hardlopen $\quad \mathrm{I} 84$

Irene Costera Meijer en Marjolein van Vossen

Voorbeeldige televisie? - Moderne en postmoderne relatievertogen

in hedendaags populair drama 202

Debat

Paul Pennings

Wat mogen we verwachten van macrokwantitatief sociaal-wetenschappelijk onderzoek? 223

\section{Bernhard Kittel}

Enkele verduidelijkingen in het debat om de gekheid van een methodologie

Summaries 234

Over de auteurs 237 
Oostveen, W.P. (2002 en 2003) Buurtmonitor Gemeente Capelle aan den IJssel. Enschede: Febodruk.

Palen, J.J. (I995) The Suburbs. New York: McGraw-Hill.

Park, R.E. \& E.W. Burgess (1967/1925) The City. Chicago: University of Chicago Press.

Saal, C.D. (1972) Dorp en route, waartoe en waarheen? De Gids 4: 10-15.

Smith, N. (1996) The new urban frontier: gentrification and the revanchist city. New York \& London: Routledge.

Snel, E. (2003) De vermeende kloof tussen culturen (oratie). Enschede: Universiteit van Twente.

Snel, E., J. Burgers, B. Steijn, A. Leerkes \& J. Veenman (2002) Klassenpositie van allochtonen in de postindustriële economie. Sociale Wetenschappen $46(3): 52-72$.

Uitermark, J. \& J.W. Duyvendak (2004) Civilizing the European city: revanchist urbanism in Rotterdam, the Netherlands. Paper prepared for the session 'new communities' at the Annual Meeting of the American Sociological Association, San Francisco, I4-I7 August 2004

Wilson, W.J. (1978) The declining significance of race. Blacks and changing American institutions. Chicago: The University of Chicago Press.

Wilson, W.J. (1987) The truly disadvantaged. The inner city, the Underclass, and public policy. Chicago: The University of Chicago Press.

Wouden, H.C. van der (1996) De beklemde stad. Grootstedelijke problemen in demografisch en sociaal-economisch perspectief. Rijswijk: Sociaal en Cultureel Planbureau.
Hester Dibbits

\section{NIEUW MAAR VERTROUWD}

Migranteninterieurs, sociale klasse en etniciteit*

\begin{abstract}
'Marokkanen zijn gek op hoogglanzend behang met drukke motieven, hoe glimmender hoe beter, zeg maar oud-jordanees'. Aldus de eigenaar van een behangwinkel in Amsterdam West (Beusekamp 2003). Aan huisraad kunnen zich allerlei connotaties hechten, en dus óók etnische. Op grond van recente studies naar migranteninterieurs lijkt de conclusie gerechtvaardigd dat woninginrichting in hoge mate klassebepaald is en het uiteindelijk niet veel uitmaakt waar mensen wonen. Dibbits waarschuwt echter voor te snelle conclusies. De uiteenlopende connotaties die zich aan huisraad hechten kunnen juist voor verrassende doorkruisingen van klassenverschillen zorgen.
\end{abstract}

'Toon mij uw woning en ik zal zeggen wie u bent'. Deze variant op een bekende uitspraak berust op het misverstand dat woninginrichting de persoonlijke identiteit weerspiegelt. Een misverstand, omdat de wijze waarop iemand zijn huis inricht slechts een onderdeel is van identiteit, net als de taal die iemand spreekt of de kleding die iemand draagt. Het geheel maakt iemand tot degene die hij of zij is, maar de verschillende onderdelen hoeven niet noodzakelijkerwijs met elkaar te rijmen, of het grotere geheel te weerspiegelen. Een individu kan bovendien de inrichting zelden helemaal alleen en precies naar eigen wens bepalen. Er zijn meestal meer mensen bij betrokken, terwijl bijna iedereen tevens te maken heeft met beperkingen wat betreft beschikbare ruimte, goederen, tijd en geld. Ten slotte spelen sociale conventies mee bij de inrichting, ongeacht of men zich nu tegen die conventies afzet of dat men zich daar juist aan houdt. Een deel van deze ongeschreven regels krijgen mensen met hun opvoeding mee, met andere wordt men op latere leeftijd geconfronteerd door omgang met mensen uit andere milieus (Bourdieu I979). In de praktijk bestaat er daarom geen scherpe scheidslijn tussen datgene wat mensen zelf bepalen bij de inrichting van hun woning en datgene wat wordt bepaald.

Meestal wordt in beschouwingen over de sociale aspecten van woninginrichting, in navolging van Bourdieu (I979), de nadruk gelegd op klassenverschillen die daarin zichtbaar zouden worden. Naast sociale klasse kunnen echter tal van andere variabelen een rol spelen. Dit artikel richt zich speciaal op migranten en hun nakomelingen, en onderzoekt in hoeverre behalve sociale 
klasse ook de migratiegeschiedenis en vooral etniciteit bepalend zijn bij de inrichting van de woning.

Niet alleen diverse buitenlandse studies over migranten en hun (woon-) cultuur nodigen uit tot een dergelijke reflectie, maar ook de eerste (grotendeels nog ongepubliceerde) resultaten van het in 2003 gestarte project Migratie en Materiële Cultuur; de interieurs van twintigste-eeuwse migranten en hun nakomelingen (Becker 2003, Van der Horst en Messing 2003, Dickson 2004, Bendrif 2004, Poot 2004, Meulendijks 2004, Van der Horst 2005a, 2005b \& 2005c, Messing 2005).

Tot nu toe richtte het onderzoek naar interieurs van migranten zich telkens op één specifieke migrantengroep. Bij vergelijking is er echter een aantal interessante overeenkomsten te zien. Het meest opvallend is dat diverse onderzoekers afzonderlijk onder de door hen bestudeerde groepen migranten een brede voorliefde signaleren voor interieurs met glanzende, nieuwe meubels, uitstallingen van veelal in massaproductie vervaardigde siervoorwerpen, en kleedjes van kant of plastic (o.a. Heinze 1990; Leatemia I992; Joy e.a. I993; Hasirci 200I; Kilickiran 2002; Becker 2003, Van der Horst 2005a, 2005b \& $2005 \mathrm{C}$, Messing 2005, Miller I994). Daarnaast wordt door vrijwel alle onderzoekers de aanwezigheid besproken van toeristische souvenirs en andere voorwerpen uit het land van herkomst (o.a. Cammaert I985; Mehta \& Belk I99I; Leatemia I992; Joy e.a. I993; Hasirci 200r; Becker 2003; Dickson 2004, Meulendijks 2004, Van der Horst 2005b).

De meeste auteurs besteden in hun analyse weliswaar aandacht aan de sociale positie, de migratiegeschiedenis en de etnische identificaties van de leden van de bestudeerde groep, maar in geen van de studies wordt uitvoerig ingegaan op het ingewikkelde samenspel van variabelen bij de keuzes die migranten maken bij de inrichting van hun woning in het land van vestiging. Ik heb ervoor gekozen om dit hier wel te doen. Naast het werk van Bourdieu vormt dat van de socioloog Herbert Gans daarbij een belangrijk referentiekader. In The Urban Villagers, zijn in 1962 verschenen monografie over de Italiaanse migrantengemeenschap in de multi-etnische wijk West End in Boston, constateert hij dat veel van het door onderzoekers als etnisch bestempelde gedrag van Europese migranten in Amerika in werkelijkheid grotendeels klassegebonden is. Hij erkent wel dat er verschillen bestaan tussen bijvoorbeeld de Italiaanse en Ierse migranten, maar het merendeel van die verschillen kan volgens Gans verklaard worden vanuit de sociaal-economische omstandigheden waarmee beide groepen reeds in het land van herkomst te maken hadden (238).

In het in 1979 verschenen artikel 'Symbolic ethnicity: the future of ethnic groups and cultures in America' herhaalt Gans deze stelling. Het centrale betoog richt zich nu echter op een ander thema, namelijk op de manier waarop nakomelingen van migranten omgaan met de cultuur van hun (voor-)ouders. Gans' stelling, die ook terug te vinden is in zijn artikel 'Symbolic ethnicity and symbolic religiosity' uit I994, is dat de nakomelingen op den duur afstand zul- len nemen van deze cultuur (hij noemt dit 'the older ethnic culture') en alleen nog blijk zullen geven van onderlinge etnische verbondenheid door middel van etnische symbolen in de vorm van bijvoorbeeld consumptiegoederen. Volgens Gans doet dit verschijnsel zich vooral voor bij de in maatschappelijk opzicht geslaagde tweede en latere generaties. Ook hier ziet Gans klasse dus als een belangrijke variabele. Voortbordurend op Gans zouden we de hypothese kunnen formuleren dat de constructie van etnische identiteiten door middel van etnische symbolen een klassegebonden fenomeen is.

Gans' analyse heeft betrekking op Europese migranten in de Verenigde Staten en woninginrichting speelt geen centrale rol in zijn beschouwingen. Zijn visie lijkt echter bevestigd te worden in diverse studies naar migranteninterieurs: ook daarin is sprake van een eerste generatie migranten met een consumptiepatroon dat veel overeenkomsten vertoont met die van de (autochtone) arbeidersklasse, en het bestaan van middle class nazaten die de herkomst van hun ouders door het etaleren van etnische symbolen in huis halen. In de volgende paragrafen gaan wij nader op deze bevindingen in.

\section{Nieuwe spullen voor de sier}

Opmerkelijk bij de door onderzoekers gesignaleerde voorkeur onder migranten voor glanzende, nieuwe (of nieuw uitziende) meubels en uitstallingen van siergoed, is dat het daarbij vaak gaat om migranten van de eerste generatie. Een studie waarin het verschijnsel uitvoerig ter sprake komt, is die van Heinze naar Joodse migranten in Amerika rond I900. Heinze beschrijft hoe voor deze groep Amerikaanse massaconsumptiegoederen - door de autochtone elite als goedkoop en tawdry (opzichtig en smakeloos) beschouwd - symbool kwamen te staan voor het door hen begeerde Amerikaanse burgerschap en hoe zij zich - al dan niet op krediet - al snel na aankomst allerlei dure en luxueuze Amerikaanse meubels aanschaften (1990). Hetzelfde wordt gemeld in Canadees onderzoek naar Italiaanse arbeiders die zich in de loop van de vorige eeuw in Montreal vestigden. Ook zij schaften zich, zodra hun economische situatie dit toestond, veel nieuwe meubels en andere spullen voor in huis aan. Een belangrijk verschil met de Poolse Joden is dat de Italianen juist de voorkeur gaven aan Italiaanse producten (Joy e.a. I993).

Behalve aan de voorliefde voor interieurs met nieuwe spullen, wordt in verscheidene studies aandacht besteed aan het niet of zelden gebruiken van eenmaal aangeschafte spullen. Bij Heinze lezen we bijvoorbeeld hoe de parlour zich ontwikkelt tot een soort pronkkamer die alleen op speciale religieuze dagen gebruikt wordt. Het Canadese onderzoeksteam vermeldt de gewoonte van Italiaanse migranten in Montreal om de hele bovenverdieping van hun huis voor speciale gelegenheden te reserveren. Daarom is al het meubilair daar voorzien van plastic beschermhoezen, terwijl het dagelijks leven zich in het 


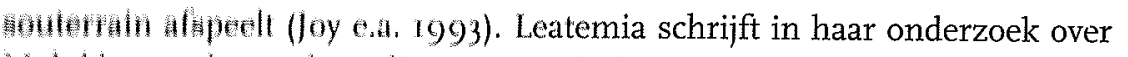
Molukkerten hun nakomelingen in Nederland dat diverse door haar bezochte familien dure nieuwe spullen aanschaffen maar deze vervolgens niet gebruiken. Een Moluks stel bijvoorbeeld bleek de gloednieuwe luxe open keuken uitsluitend te gebruiken voor het bereiden van koffie en thee; gekookt werd in het oude keukentje op de benedenverdieping (Leatemia I992).

Kijken we naar het onderzoek dat onder Turken in Nederland en Duitsland is verricht, dan valt op dat de meeste Turkse gezinnen uit het Nederlandse onderzoek veel belang hechten aan een woning met nieuwe meubels en nieuwe accessoires in het land van vestiging, terwijl onder Turken in Duitsland overwegend sobere, op functionaliteit ingerichte interieurs werden aangetroffen (Dibbits 2000, Hasirci 200I; Van der Horst 2005b; Çaglar r998). Een verklaring zou mogelijk een verschil in financiële situatie kunnen zijn, ware het niet dat de Duits-Turkse families wel investeren in nieuwe consumptiegoederen voor hun woning in het land van herkomst. Çaglar verbindt dit aan de wens ooit terug te keren naar Turkije (I998).

In het onderzoek onder Marokkaanse migranten in België, Nederland en Italië zijn geen aanwijzingen voor een dergelijk verschil tussen de diverse migratielanden te vinden (Cammaert r985; Dickson 2004; Bendrif 2004; Salih 2002; Gandolfi 2004). Wel is duidelijk dat ook in deze groep velen ervoor kiezen om te investeren in nieuwe spullen voor de woning in het land van herkomst. Salih brengt dit, anders dan Çaglar, in verband met het gegeven dat in veel gezinnen een praktijk is ontstaan waarbij men tijdelijk verblijf in het land van herkomst afwisselt met tijdelijk verblijf in het land van vestiging (Salih 2002). Overigens signaleert zij wel een zekere mate van afkeuring over de investeringen in statussymbolen voor in het land van herkomst. Ik kom hier later op terug.

Ook in studies die niet over migranten gaan, wordt aandacht besteed aan de voorliefde voor interieurs gevuld met nieuw-ogende consumptiegoederen. Onderzoek naar de materiële cultuur in Nederland laat bijvoorbeeld zien dat in de zeventiende, achttiende en negentiende eeuw in de verstedelijkte kustgewesten het pronken met (nieuw of nieuw-ogend) huisraad met name in gemeenschappen van boeren en vissers algemeen voorkwam (o.a. Dibbits $200 \mathrm{I}$ $\&$ 2004; Schuurman I989). Voor de twintigste eeuw biedt vooral onderzoek in Noorwegen en Duitsland interessante vergelijkingsmogelijkheden. Gullestad heeft bijvoorbeeld voor Bergen (Noorwegen) beschreven hoe de opstelling van de objecten in de huizen van jonge arbeidersgezinnen een verlangen toont naar gepolijst en weelderig comfort. De indruk wordt, aldus Gullestad, vooral gecreëerd door glanzende oppervlakken met materialen als leer, glas en geverfd hout, door grote hoeveelheden planten en versieringen van glas, porselein, brons, albast en onyx, en ten slotte door een 'spotless order', waarbij alles in weloverwogen composities of zones (de zithoek, de eethoek en dergelijke) staat opgesteld, met als ideaal een strak doorgevoerde symmetrie. Gulle- stad trof weinig oude spullen aan in deze huizen. Het kopen van meubilair op vlooienmarkten of antiekmarkten bleek niet als nastrevenswaardig te worden gezien (I993).

Volgens Pallowski, die onderzoek deed naar de woonstijlen onder elite en arbeiders in West-Duitsland eind jaren tachtig, kenmerken arbeiderswoningen zich vooral door de geringe neiging van de bewoners om de strakke designmode te volgen, en door hun voorliefde voor alles wat voor de culturele elite inmiddels passé is: een brandschone woonkamer, een complete zitgroep, volumineuze meubels, en overdadige decoratie. Het enige aan design is de televisie, enkele verlichtingselementen, en misschien een enkele keer een salontafel van chroom en glas. De zitmeubels, tapijten, wandkast en decoraties tonen volgens Pallowski een doorsnee-smaak, waarin conventionaliteit verbonden wordt met een cultuur van ongedwongenheid en comfort (I99I).

\section{Sociale klasse, migratieachtergrond en etniciteit}

Dat er veel parallellen zijn tussen migranten- en arbeidersinterieurs, is niet zo verwonderlijk. Voor een belangrijk deel zijn de omstandigheden en daarmee ook de sociale strategieën voor beide groepen hetzelfde. Beide laten met hun inrichting zien dat er zorg en aandacht en geld wordt besteed aan het interieur (Gullestad I993), waarbij de naar het lijkt standaard aanwezige kunstbloemen wereldwijd een aantrekkelijke - want schone en onderhoudsvrije-sfeermaker blijken te zijn (Cammaert I985; Secondulfo I997; Katschnig-Fasch r998; Pallowski 199r; Günter r995; Gullestad I993). Door siergoed en nieuwe (of nieuw ogende) meubels neer te zetten, wordt bovendien getracht elke associatie met eventuele armoede te vermijden (Pallowski I99I; Joy e.a. I993). Met zo min mogelijk kosten probeert men een zo indrukwekkend mogelijk effect te bereiken (Pallowski I99I). Daarbij kunnen sommige spullen als symbool van welstand fungeren en niet als praktische gebruiksvoorwerpen. In families waar men bijvoorbeeld altijd gewend is om aan een lage tafel te eten, zal men het bezit van een eettafel met bijpassende stoelen misschien wel op prijs stellen, maar in het alledaags bestaan van een dergelijk meubel weinig gebruik maken (Katschnig-Fasch 1998 : 147 ).

Voor een deel is de voorliefde voor glanzende, nieuwe meubels en het uitstallen van veelal in massaproductie vervaardigde siervoorwerpen klassegebonden. Migratiegeschiedenis speelt echter op haar eigen manier ook een belangrijke rol bij de totstandkoming van het interieur. Volgens het team van onderzoekers dat de interieurs van Italiaanse migranten in Montreal bestudeerde, wordt de behoefte aan het verzamelen van - en het pronken met (nieuwe) voorwerpen versterkt door de onzekerheden die de nieuwe situatie met zich meebrengt (Joy e.a. I993). Kilickiran, die onderzoek deed onder Turks-Koerdische vluchtelingen, ziet de investeringen in dure meubels als een 
Manies om atn te geven dat het de migranten beter gaat dan in het land van herkomst (2003). Heinze wijst erop dat het pronken met consumptiegoederen voor de nieuwkomer een relatief eenvoudige methode is om te laten zien dat men het goed doet als nieuwe burger. Luxegoederen zijn immers gemakkelijker te verwerven dan intellectuele bagage (I990).

Volgens Cammaert, die in de jaren tachtig onderzoek deed onder Marokkaanse families in Brussel, spelen de kinderen een belangrijke rol bij de beslissing om tot aanschaf van nieuwe spullen voor in het huis in het land van vestiging over te gaan. Salih stelde hetzelfde vast onder Marokkaanse families in Italië: [They] push their families to search for social recognition in Italy, driving them to conform to an Italian life style, in terms of adaptation to certain kinds of commodities and fashions.' Behalve de kinderen bleken ook veel moeders zich hier nadrukkelijk op het land van vestiging oriënteren. Het is bij deze groep dat Salih een zekere afkeuring signaleert ten aanzien van migranten die hun geld sparen om in Marokko aan statussymbolen uit te geven. Voor Italiaans-Marokkaanse vrouwen, zo betoogt Salih, is de vraag waar te investeren (zowel materieel als symbolisch) onderwerp van voortdurende discussie. Het heen en weer gereis tussen beide landen zorgt daarbij voor een preoccupatie met de vraag waar 'thuis' is en dit leidt tot een paradoxale situatie: 'While keeping a simultaneous relationship with their country of origin, women paradoxically also increase their need for territorialization and secure identities' (2002: 66).

De vraag is of voor - in dit geval Marokkaanse - mannen hetzelfde geldt. Belk stelde in een onderzoek naar de persoonlijke bezittingen van negentiendeeeuwse Mormonen in Amerika namelijk vast dat vrouwelijke pioniers in persoonlijke documenten blijk geven van een mate van gehechtheid aan persoonlijke bezittingen, die niet te vinden is in persoonlijke documenten van mannelijke pioniers. Volgens Belk - één van de weinige onderzoekers op het gebied van migranten en materiële cultuur die expliciet aandacht heeft besteed aan het genderperspectief - zou dit geduid kunnen worden als een verlangen van vrouwen naar continuiteit, en van mannen naar uitdaging en verandering (I992).

Zeker is dat een huis vol met spullen niet alleen naar welstand verwijst, maar ook naar stabiliteit, en naar een leefpatroon waarbij niet al te vaak van woonplaats hoeft te worden gewisseld. Door overal kleedjes op te leggen worden objecten gedomesticeerd, en een eventuele associatie met mobiliteit naar de achtergrond verdrongen (Dibbits 200I; Kilickiran 2003). In een migratiecontext zal hieraan (door vrouwen?) mogelijk extra belang worden gehecht, juist om tegenwicht te bieden aan het mobiele element in het bestaan van de migrant. Dit zou ook verklaren waarom de inrichting van de wagens van veel woonwagenbewoners op geen enkele wijze naar een mobiel bestaan verwijst.

Impliceert het bovenstaande nu ook dat voor de tweede generatie een huis met veel nieuwe spullen minder belangrijk wordt? Volgens het Canadese onderzoeksteam is dit inderdaad het geval: 'Among second-generation immigrants, the wish for stability through objects becomes less of a concern, and further accommodation to cultural contexts occurs' (Joy e.a. I993: I49). Om deze stelling te kunnen toetsen, zouden de interieurs en de consumptiepatronen van volwassen kinderen van migranten met eenzelfde sociale positie als hun ouders met elkaar moeten worden vergeleken.

Wat de lager opgeleide nakomelingen van Turkse en Marokkaanse migranten in Nederland betreft, lijkt de stelling vooralsnog niet zonder meer te kunnen worden bevestigd. Het uitstallen van siergoed, het neerzetten van kunstbloemen en bijvoorbeeld het neerleggen van kleedjes op meubels is zeker bij jonge gezinnen weliswaar niet meer vanzelfsprekend, maar niets wijst erop dat de tweede generatie minder investeert in nieuwe meubels en ander nieuw huisraad (Hasirci 200I; Van der Horst 2005a, 2005b, 2005c; Dickson 2004; Bendrif 2004).

Wat voor rol speelt etniciteit nu in dit geheel? Op deze vraag zijn ten minste twee antwoorden mogelijk. Ten eerste valt op dat een deel van de migranten bij de aanschaf van nieuw huisraad een voorkeur heeft voor spullen uit het land van herkomst, ook als het gaat om goederen die niet direct als zodanig herkenbaar zijn. Aan het door Nederlandse en Deense Turken uit Turkije meegenomen huishoudtextiel is bijvoorbeeld voor een buitenstaander niets Turks te zien (wanneer er geen merklabeltje aanzit althans). Als verklaring worden wel de (vermeende) prijs-kwaliteitverhouding en bepaalde esthetische eigenschappen genoemd (Ger en Østergaard I998; Hasirci 200I). Mogelijk spelen echter ook gevoelens van trots op de afkomst een rol, zoals volgens het Canadese onderzoek het geval is bij de Italiaanse migranten in Montreal die het meubilair in de mooie salon ofwel uit Italië importeren, ofwel in Canada laten maken maar in Italiaanse meubelzaken kopen (Joy e.a. I993). Zeker in die gevallen waar voor een buitenstaander niet speciaals aan de meubels of goederen te zien is, zou ik hier echter niet willen spreken van etnische symbolen. De voorkeur onder migranten voor goederen uit het land van herkomst is een voorbeeld van een gegeven waarbij etnisch bewustzijn mogelijk een rol speelt, naast allerlei andere factoren.

Als antwoord op de vraag naar de rol die etniciteit speelt, kan ook worden gewezen op het gegeven dat de consumptiepatronen die hierboven zijn beschreven vaak in verband worden gebracht met een bepaalde groep migranten en een etnische connotatie krijgen toegekend. Een jonge Marokkaanse omschrijft het verschil tussen haar eigen woning en die van haar ouders bijvoorbeeld met de woorden: 'Ik heb - denk ik - een meer Westers interieur, met deze banken. Mijn ouders hebben echt Marokkaanse banken. En het ziet er iets Marokkaanser uit (...) het behang ook enzo. Ik vind dat Turken-behang. Dat is wel heel oneerbiedig, maar met al die tierelantijntjes enzo, en dan die lampen heel opvallend, veel bloemen...' (Dickson 2004: 64).

In dit voorbeeld krijgen niet alleen de traditionele Marokkaanse banken, de zogeheten sedari, maar ook het behang, de lampen en de (kunst-)bloemen door iemand anders dan de bewoners zelf, een etnische connotatie toegekend. Met 
uitzondering van de traditionele Marokkaanse banken zullen de meeste spullen niet direct herkenbaar zijn als 'typisch Marokkaans'. De dochter noemt het behang zelfs 'Turken-behang', terwijl de winkelier uit het citaat in de lead bij dit artikel hetzelfde behang misschien als 'oud-Jordanees' zou hebben bestempeld. Wat de ouders van dit meisje van hun eigen interieur denken weten we niet, maar we mogen ervan uitgaan dat zij het merendeel van de spullen niet speciaal hebben neergezet als 'etnische symbolen'.

Wanneer is er dan sprake van de etnische symbolen waar Gans op doelde? In de volgende paragraaf zal ik nader op deze vraag ingaan, onder andere aan de hand van het soort voorwerpen dat de informante in haar eigen woning heeft staan, zoals de door haar zelf in Marokko of in Marokkaanse winkels gekochte tajines, theeglaasjes, en kleedjes, hennalamp, foto's van de Marokkaanse koning en Koranbord (Dickson 2004). Deze voorwerpen maken deel uit van het zogeheten materieel erfgoed; materiële cultuuruitingen die door verschillende generaties als onderscheidend worden ervaren voor en door een bepaalde groep.

\section{Materieel erfgoed}

De Palestijnse filmer Masharawi schreef in 1998 in zijn videodagboek over zijn verblijf in de Utrechtse wijk Lombok:

Wanneer je een huis binnenkomt waar buitenlanders wonen, Turken bijvoorbeeld, dan zie je dat de muren vol hangen met schilderijen en versieringen die ofwel heel religieus zijn of gewoon heel erg Turks. Deze versieringen schreeuwen uit naar de bezoekers: 'Ik ben Turks - Ik ben moslim!' Het lijkt wel alsof deze versieringen slogans zijn die de inwoner nodig heeft om zijn/haar identiteit te handhaven. Deze versieringen zijn externe dingen die hem/haar constant aan zijn/haar vaderland herinneren; en een gekristalliseerde identiteit hebben (Masharawi r998).

Het zou onjuist zijn uit dit citaat af te leiden dat Masharawi hier een alom tegenwoordige aanwezigheid van etnische symbolen vaststelt. Onder de objecten waar Masharawi op doelt, zullen zich immers veel in Turkije algemeen gangbare decoraties en alledaagse voorwerpen bevinden, die voor de bewoners belangrijk zijn om zich 'thuis' te voelen in een vreemde omgeving (Roth I999).

Interessant is echter dat bij migranten en hun nakomelingen ook veel voorwerpen staan die niet gangbaar zijn in het land van herkomst. In een artikel over consumptie en de constructie van sociale identiteit onder Turkse jongeren merken Ger en Østergaard bijvoorbeeld (zijdelings) op dat zij veel toeristische souvenirs uit Turkije aantroffen in de woningen van de ouders van deze jongeren (I998). Mehta en Belk zagen bij de door hen bezochte Indiase migranten in de VS allerlei Indiase voorwerpen, die in India zelf niet in woonhuizen stonden (1991).

Sommige informanten blijken, als er gericht naar wordt gevraagd, te kunnen aangeven waarom zij dergelijke voorwerpen neerzetten. Zo zegt een Creools-Surinaamse student over de - naar zijn idee in Suriname niet gangbare - houten klok in de vorm van Suriname: 'Surinamers in Nederland hebben vaak zo'n klok hangen... Ik weet niet of het iets betekent, maar waarschijnlijk is het iets van nostalgie of zo, een band houden met Suriname... Ik heb hem ook gekocht om dat uit te dragen' (Poot 2004).

Behalve de klok en een plakkaat van Suriname heeft deze student ook afbeeldingen van Martin Luther King en Nelson Mandela in zijn kamer hangen. Deze portretten verwijzen niet naar Suriname, maar naar de geschiedenis van zwarte bevolkingsgroepen. In de literatuur wordt doorgaans weinig aandacht besteed aan de aanwezigheid van dergelijke objecten, die niet zozeer nationale, maar andersoortige etnische identificaties (kunnen) vertegenwoordigen. Men kan dan behalve aan bovengenoemde voorbeelden denken aan Indiase souvenirs bij Hindostaanse Surinamers (Messing 2005) en Oosterse of Arabische voorwerpen bij respectievelijk Chinese en Marokkaanse migranten. Dit soort voorwerpen verdient speciale aandacht. Net als de souvenirs uit Turkije en India bij respectievelijk de Turkse en Indiase migranten, kunnen deze immers bij uitstek als etnische symbolen fungeren. Interessant in dit verband is de conclusie in het onderzoek van Meulendijks naar de wooncultuur van drie generaties Indische Nederlanders. Zij trof bij de tweede en derde generatie niet zozeer méér verwijzingen naar het land van herkomst aan, maar wel een ander soort. Stonden bij de eerste generatie relatief veel erfstukken uit Nederlands-Indië, bij de latere generaties trof zij naast Indonesische souvenirs vooral veel Aziatische spullen aan en objecten met een 'Oosters uiterlijk' (2004).

Sommige religieuze voorwerpen zouden eveneens tot de categorie andersoortige - want niet nationaal-etnische - symbolen gerekend kunnen worden (Gans I994). Nader onderzoek moet uitwijzen of in het geval van de Koranborden in met name Turkse en Marokkaanse interieurs gesproken kan worden van etnisering van religie, waarbij de gemeenschappelijkheid van geloof belangrijker wordt gevonden voor de groepscohesie dan de uiteenlopende regionale herkomst (Schrover 1999). Bij een dergelijk onderzoek zou dan wel rekening gehouden moeten worden met het gegeven dat Koranborden in Marokko en Turkije zelf ook gemeengoed zijn. Mogelijk betreft het hier een grootschaliger proces van etnisering van religie.

Alvorens stil te staan bij de vraag of wij het zogeheten materieel erfgoed uit het land van herkomst dat bij migranten en vooral bij hun nakomelingen in huis staat als etnische symbolen mogen beschouwen, besteden we eerst aandacht aan twee zaken die Gans in zijn artikel uit 1979 als karakteristieke kenmerken noemde van deze symbolen. 
Etnische symbolen ontlenen hun kracht vooral, zo betoogde Gans in I979, atan het gegeven dat zij niet al te diep ingrijpen in het dagelijks doen en laten van mensen. Het onderzoek van Metha en Belk lijkt deze veronderstelling te bevestigen: de migranten uit India cultiveerden niet de in het dagelijks leven diep-ingrijpende tradities als het kastensysteem of specifieke Indiase opvoedingspraktijken, maar juist de gemakkelijker te cultiveren onderdelen van het repertoire. Men vond het belangrijker om Indiaas eten te blijven eten en Indiase kleren te dragen, dan om zich aan de voedselwetten te houden. Het meeste belang hechtte men aan de 'appearance of being Indian', zonder dat dit al te veel gevolgen had voor het dagelijkse doen en laten (I99I). In zijn in I994 verschenen artikel 'Symbolic ethnicity and symbolic religiosity', tekent Gans overigens aan dat ook schijnbaar oppervlakkige symbolen natuurlijk wel een belangrijke emotionele betekenis kunnen hebben. Zoals Van der Horst recentelijk terecht heeft opgemerkt, laat Gans nu echter na in het verlengde hiervan te wijzen op de ingrijpende gevolgen die juist dit gegeven kan hebben (2005b).

Voor een tweede door Gans genoemd kenmerk van symbolische etniciteit, namelijk dat het een verschijnsel is dat zich voordoet bij latere generaties, die bovendien deel uitmaken van de middle class, lijkt het interieuronderzoek onder migranten verschillende aanwijzingen te leveren. Een bevestiging van het generationele aspect bieden onder andere de studies van Becker en Leatemia naar respectievelijk de Chinezen en Molukkers in Nederland; in diverse migrantenfamilies voegden (volwassen) kinderen van migranten op eigen initiatief door middel van geschenken (kleinigheidjes, maar ook meubels bijvoorbeeld) verwijzingen naar de herkomstregio toe aan het interieur van hun ouders (Leatemia I992; Becker 2003).

Het onderzoek van Mehta en Belk zou als bevestiging kunnen worden gezien van de stelling dat symbolische etniciteit vooral een middenklasseverschijnsel is omdat Mehta en Belk veel verwijzingen naar India aantroffen onder hun hoogopgeleide, middenklasse-informanten. Wel moet daarbij worden aangetekend dat laagopgeleide migranten geen deel uitmaakten van hun onderzoek.

Kijken we naar de eerste resultaten van het onderzoek onder Marokkaanse Nederlanders in het kader van het project Migratie en Materiële Cultuur, dan blijken de zaken toch minder eenvoudig te liggen (Dickson 2004; Bendrif 2004). Ruim de helft van de 46 informanten met wie tot nu toe gesproken is, heeft in zijn Nederlandse woonhuis traditionele Marokkaanse banken staan of gaf aan deze zogeten sedari te willen aanschaffen. De sedari blijken in trek bij jong en oud, en zowel bij eerste als tweede generatie. Het betreffen hier niet meubels die alleen populair zijn bij Marokkanen uit de middenklasse, maar bij een veel breder publiek. De aanschaf van sedari zorgt meestal voor ingrijpende veranderingen in het interieur. Sommigen zetten de banken in een aparte kamer, die dan als Marokkaanse salon wordt ingericht. Anderen zetten ze in de dagelijkse woonkamer, waar dan niet zelden ook het reeds aanwezige 'Europese' bankstel blijft staan.

Hebben we hier nu te maken met een etnisch symbool? Het antwoord is afhankelijk van het perspectief. Kijken we naar de redenen die door informanten zelf worden genoemd om de sedari aan te schaffen, dan dient zich een scala aan mogelijke duidingen aan. Een enkeling zegt expliciet sedari te willen kopen om uitdrukking te geven aan zijn of haar Marokkaanse achtergrond. Maar er worden ook tal van andere redenen gegeven. Meestal wijst men erop dat het zo handig is als er logés zijn; er kunnen veel mensen op. Of men zegt: het is praktisch in het onderhoud, je hoeft alleen de stof maar te verwisselen. En sommigen laten eenvoudigweg weten: iedereen heeft er één, en ik wilde er daarom ook één.

We hoeven niet te verwachten dat voorwerpen die door een onderzoeker als etnische symbolen worden geduid, door informanten in dezelfde termen worden omschreven. De eerder genoemde jonge Marokkaanse uit het onderzoek van Dickson zei nadrukkelijk dat er voor haar geen diepere betekenis zit achter de Marokkaanse voorwerpen die zij in haar huis heeft staan: 'Ik koop het gewoon als ik het zie.' Het is echter goed denkbaar dat haar reflecties op slag zouden veranderen als zij de scriptie waarvoor zij werd geïnterviewd zou hebben gelezen. De scheidslijn tussen het bewust of onbewust neerzetten van objecten als etnisch symbool is niet gemakkelijk te trekken en reflecties over voorwerpen kunnen van moment tot moment verschillen. ${ }^{\mathrm{I}}$ Als onderzoeker ben ik in elk geval geneigd om, ongeacht hetgeen de informanten zeggen, zowel de sedari als de souvenirs als ethnic symbols te beschouwen, omdat het objecten zijn die voor derden direct herkenbaar zijn als verwijzingen naar (in dit geval) het land van herkomst.

Dit betekent natuurlijk niet dat de verhalen van de bezitters er niet toe doen. Integendeel zelfs. Interessant is bijvoorbeeld dat de Marokkaanse Nederlandse uit bovenstaande alinea's een duidelijk onderscheid maakt tussen traditioneel vervaardigde souvenirs en massaproducten. Bij één van de souvenirs, een maquette van een schip, merkt ze op: 'Dat schip heb ik in Agadir gekocht [...] en dit was dan door die man zelf gemaakt [...] ik heb helemaal niks met zeilen, maar ik vond het gewoon mooi dat hij dat zelf maakte.' (Dickson 2004: 66) Eenzelfde soort onderscheid tussen 'oud' en 'nieuw' zien we bij een in Nederland geboren en getogen jonge man uit een Moluks migrantengezin, die in zijn woonkamer een vitrinekast geplaatst had voor een speciaal voor hem op Ambon gemaakt bootje en twee 'echte oude', in een antiekwinkel in Yogjakarta aangeschafte, wajang poppen, terwijl elders in huis de voor het grote publiek vervaardigde souvenirs uit souvenirwinkels werden bewaard (Leatemia 1992).

Door de eigenaars wordt in dit soort gevallen dikwijls niet de associatie met afkomst of familiegeschiedenis als belangrijkste reden gegeven om souvenirs een prominente plaats in het interieur toe te kennen, maar het visuele plezier dat men beleeft aan het object en, in het geval van de traditioneel vervaardigde 
souvenirs, aan de wetenschap hoe, waar, wanneer en door wie het is gemaakt. De onderzoeker kan vervolgens vaststellen dat de eigenaar aan het bezit van authentieke objecten naast plezier ook prestige ontleent in maatschappelijke (middenklasse) circuits waar 'authentieke' souvenirs aanzien genieten. Dit prestige kan (mede) verklaren waarom sommige geïnterviewden nadrukkelijk onderscheid maken tussen de verschillende soorten souvenirs (zie ook Van der Horst 2005b).

\section{Tot besluit}

Migratieachtergrond, sociale klasse en etniciteit spelen alledrie een belangrijke rol bij de inrichting van de woningen van migranten en geven inzicht in zowel de voorliefde voor nieuwe spullen, als in de aanwezigheid van souvenirs en andere voorwerpen uit het land van herkomst. De precieze rol van de afzonderlijke factoren bleek echter in het ene geval gemakkelijker waarneembaar dan in het andere.

De migratieachtergrond levert een voor de hand liggende verklaring waarom eerste-generatie migranten een voorliefde tonen voor een huis vol met nieuwe spullen; het biedt compensatie voor het mobiele element in het bestaan, en voor de bij veel migranten aanwezige gevoelens van onzekerheid over de toekomst. Objecten geven vaste voet aan de grond en vormen voor twijfelaars een bevestiging van de stap die ze hebben gezet. Door de aanschaf van nieuwe objecten neemt men een voorschot op de toekomst. Bij migranten met een rurale of arbeidersachtergrond kan de voorliefde voor het glanzende meubilair en het siergoed ook voortkomen uit een streven om iedere associatie met armoede en schaarste te vermijden. De rol die etniciteit speelt bij de gesignaleerde voorkeur voor glanzende, nieuwe meubels en uitstallingen van dikwijls in massaproductie vervaardigd siergoed is minder evident. We zagen dat de aanwezigheid van bijvoorbeeld glimmend behang of grote kristallen lampen dikwijls door anderen etnisch wordt geduid, terwijl deze voor de bewoners zelf geen etnische connotatie hebben. Bij consumptiegoederen die speciaal uit het land van herkomst geïmporteerd zijn, ligt dit wel voor de hand, ook al zijn zij voor buitenstaanders wellicht niet direct als zodanig herkenbaar.

Ook de aanwezigheid van zogeheten materieel erfgoed in migranteninterieurs kan vanuit de drie hier centraal gestelde factoren verklaard worden. Heel duidelijk speelt de migratieachtergrond een rol waar souvenirs uit het land van herkomst in de woning zijn neergezet als dierbare herinneringen aan het land van herkomst, aan verwanten die daar wonen, of aan belangrijke persoonlijke gebeurtenissen die men daar meemaakte. Met name bij de tweede en latere generaties worden als materieel erfgoed beschouwde objecten ook wel (bewust of onbewust) neergezet om uitdrukking te geven aan een gevoel van etnische verbondenheid. Als zodanig zijn het mooie voorbeelden van de etnische symbolen waar Gans op doelt in zijn artikel over symbolische etniciteit.

Is de aanwezigheid van zogeheten materieel erfgoed ook een klasse-gerelateerd verschijnsel en heeft Gans gelijk met zijn theorie over symbolic ethnicity? Moeten we wellicht nog zelfs een stap verder gaan en ook Bourdieu gelijk geven omdat ook veel autochtonen uit de middenklasse immers souvenirs uit verre landen in huis hebben staan en tussen de interieurs van middenklasse autochtonen en middenklasse migrantennakomelingen zo beschouwd weinig verschil is te zien?

Er zijn ten minste twee redenen om terughoudend te zijn met een dergelijke conclusie. Ten eerste laat de belangstelling onder Marokkanen voor de sedari zien dat er binnen een migrantengemeenschap een ontwikkeling kan plaatsvinden waarbij, dwars door verschillende lagen van de gemeenschap heen, een brede belangstelling ontstaat voor traditionele objecten (waarvan de aanschaf ingrijpende gevolgen kan hebben voor het interieur). Die ontwikkeling kan een onderdeel zijn van een algemeen proces van traditionalisering (Dibbits 200I), maar het kan ook een tijdelijke modetrend zijn. Niet onbelangrijk daarbij is het aanbod (Domke 2002). In het geval van de sedari bijvoorbeeld, lijkt een belangrijke impuls de opening van een grote Marokkaanse meubelfirma in Rotterdam in 2002 te zijn geweest (Dickson 2004; Dibbits 2005).

Met de brede voorliefde voor de sedari en de wens om een aparte ontvangstsalon te kunnen inrichten, lijkt de Marokkaanse gemeenschap in Nederland zich te onderscheiden van de Turkse gemeenschap, die een vergelijkbare interieurtraditie kent wat betreft banken en ontvangstkamers en hier in theorie dus óók op zou kunnen 'teruggrijpen'. De belangstelling voor traditioneel meubilair beperkt zich hier vooralsnog echter tot een kleine groep van voornamelijk hoger opgeleide Turken. Veel behoefte aan een aparte ontvangstkamer lijkt er bij deze groep niet te bestaan en ook andere Nederlandse Turken kennen hier geen hoge prioriteit aan toe (Van der Horst 2005c).

Behalve traditionaliseringsprocessen die (door het bewuste of onbewuste gebruik van etnische symbolen) het ontstaan van ook in cultureel opzicht verschillende etnische groepen in een samenleving tot gevolg kunnen hebben, is er nog een reden om bij de studie naar interieurs niet uitsluitend op klassenverschillen te focussen. Achter dezelfde objecten, of het nu de glanzende nieuwe meubels betreft of de souvenirs uit verre landen, kunnen immers verschillende gebruiks- en betekenisrepertoires schuilgaan.

De manier waarop mensen in het dagelijks leven omgaan met voorwerpen, of met hun woning, kan worden beschouwd als een onderdeel van hun culturele repertoire. Dat repertoire kan uniek zijn voor een groep, maar dat hoeft niet. Het kan worden toegeëigend door mensen uit andere groepen en mensen kunnen aspecten van een repertoire met elkaar delen (Frijhoff I997 \& 2003). Zo kunnen er overeenkomsten zijn tussen de interieurs van migranten en 
autochtone arbeiders, maar de betekenissen die aan de verschillende delen van het repertoire worden toegekend, hoeven daarmee nog niet hetzelfde te zijn of te blijven. Ook binnen een groep kunnen verschillen bestaan in betekenistoekenning. Door de één kan een bepaald deel van het repertoire worden beschouwd als een wezenlijk onderdeel van zijn eigen identiteit, terwijl een ander daar juist weinig belang aan hecht. Dit geldt ook voor nakomelingen van migranten die traditionele voorwerpen uit het herkomstland van hun ouders in huis hebben staan; deze kunnen door henzelf als wezenlijk onderdeel worden beschouwd van hun etnische identiteit, maar dat hoeft niet. Ook datgene wat als 'wezenlijk' voor een etnische identiteit wordt beschouwd, kan weer al naar gelang de context variëren en heeft zowel te maken met zelfdefiniëring als met de toeschrijving van bepaalde kenmerken door anderen (Barth I969).

De betekenissen die mensen toekennen aan de objecten waarmee zij zich omringen zijn daarom gelaagd en kunnen zelfs op individueel niveau in combinatie voorkomen. Een duur schilderij boven een bank in een woonkamer kan dierbare herinneringen oproepen, het kan 'gewoon mooi' zijn en het kan fungeren als symbool van maatschappelijk succes of etnisch bewustzijn uitdragen. Met de buitenwereld in gedachten kan men ervoor kiezen - bijvoorbeeld uit angst voor vervolging-om een politieke afbeelding niet op te hangen, of om het juist wél te doen, als vorm van zelfbevestiging. Illustratief in dit verband is de vaststelling dat Turks-Koerdische vluchtelingen in Londen hun woning daar vooral zien als ruimte waar zij zich, anders dan in Turkije zelf, vrij voelen om hun Koerdische identiteit vorm te geven (Kilickiran 2003). Ook het eerder genoemde koranbord dat bij veel nazaten van Turkse en Marokkaanse migranten in Nederland wordt aangetroffen is een voorbeeld van een voorwerp met vele betekenissen. Terwijl afbeeldingen van tulpen en klompen, ook in interieurs van migranten, een eenduidige connotatie hebben - Holland verwijst zo'n koranbord naar meer dan religie alleen. Datzelfde geldt voor de huisaltaren van Hindoestanen, die in de huiskamer staan opgesteld (Messing 2005) of voor het min of meer willekeurige 'heilige voorwerp' dat voor veel Creoolse Surinamers een vanzelfsprekend onderdeel van de woninginrichting is. ${ }^{2}$ Pas door de context te bestuderen, komen de verschillende betekenislagen
in beeld.

\section{Noten}

Dit artikel is geschreven in het kader van het onderzoeksproject 'Migratie en Materiële Cultuur. De interieurs van twintigste-eeuwse migranten en hun nakomelingen'. Het betreft hier een door Nwo medegefinancierd samenwerkingsproject van het Meertens Institut (KNAw) en Siswo/Instituut voor Maatschappijwetenschappen. Het project, dat nog loopt tot begin 2007 , zal onder andere resulteren in een algemene publicatie over migratie en materiële cultuur en twee dissertaties: één van Hilje van der Horst over de interieurs van Turkse Nederlanders en hun nakomelingen en één van Jantine Messing over de interieurs van
Hindostaans-Surinaamse Nederlanders en hun nakomelingen. Zie voor een projectbeschrijving http://www.meertens.knaw.nl/medewerkers/hester.dibbits/migration.pdf.

Voor de totstandkoming van dit artikel ben ik speciale dank verschuldigd aan Kitty Roukens, mede-auteur van bovengenoemde projectbeschrijving en collega-onderzoeker in het project. Tevens wil ik hier de redactie van Sociologie bedanken voor hun commentaar op eerdere versies van dit artikel.

1 Gans stipt dit aspect kort aan in zijn artikel 'Symbolic ethnicity and symbolic religiosity' (I994). Hij schrijft hier, terugblikkend op het artikel uit I979: 'Perhaps I was then unsure how seriously people treated symbolically ethnic activities. However, two major studies, by Alba (1990) and Waters (I990), indicate that symbolic ethnicity covers a wide range of ethnic identifications. Some people use it as a way to express their individuality or a special communal allegiance that does not conflict with other identities, while for many it is little more than a label they recall when asked the right interview question. For most, it is something in between' (I994: 579). Gans problematiseert dit gegeven echter niet.

2 Voor deze 'heilige voorwerpen' baseer ik mij op de bevindingen van Kitty Roukens en drie stagiairs tijdens hun onderzoek naar de interieurs van Creools-Surinaamse Nederlanders.

\section{Literatuur}

Barth, F. (1969) Introduction. In: F. Barth (red.) Ethnic groups and boundaries. The social organization of cultural difference. London: Allen \& Unwin, 9-38.

Becker, S. (2003) Achter gesloten deuren. Materielle Cultuur en Etnische Identiteit van Chinese Nederlanders. Doctoraalscriptie Cultuursociologie. Universiteit van Amsterdam.

Belk, R.W. (1992) Moving Possessions: An Analysis Based on Personal Documents from the I847-I869 Mormon Migration. Journal of Consumer Research I9, 339-36I.

Bendrif, A. (2004) Interieurs van Marokkaanse migranten en hun nakomelingen. Veldwerkverslagen, Meertens Instituut Amsterdam (KNAW).

Beusekamp, W. (2003) Glimbehang als wandbekleding. De Volkskrant 30 december. Bourdieu, P. (1979) La Distinction. Critique sociale du jugement. Parijs: Minuit.

Çaglar, A. (I998) Die zwei Lebens eines Couchtisches. Historische Anthropologie 6 (2) 242-256. N B: ook verschenen als: Çaglar, A. (2002) A table in two hands. In: D. Kandiyoti and A. Saktanber (red.) Fragments of culture, the everyday of modern Turkey. Londen: I.B. Taurus, 294.307.

Cammaert, M.-F. (1985) Migranten en thuisblijvers: een confrontatie. De leefivereld van Marokkaanse Berbervrouwen. Leuven: Universitaire Pers.

Dibbits, H. (2000) 'In Turkije gaat het tegenwoordig net zo.' De culturele repertoires van een Turks gezin in een multi-etnische wijk. Amsterdams Sociologisch Tijdschrift 27 (3) 314-344. Dibbits, H. (2001) Vertrouwd bezit. Materiële cultuur in Doesburg en Maassiuis, 1650-1800. Nijmegen: Sun.

Dibbits, H. (2004) Pronk op papier. Boedelbeschrijvingen als bron voor lokaal historisch onderzoek. In: H. Michielse, E. de Paepe en G. Schutte (red.) Lokale geschiedenis tussen lering Q vermaak. Hilversum: Verloren, 7I- 87 .

Dibbits, H. (2005) Onderzoek naar interieurs van migranten en hun nakomelingen in Nederland. De woonspotkrant. Onafhankelijk maandblad voor de wonenbranche I (2) 22.

Dickson, S. (2004) De Migrantenwoning: van huis naar thuis. Een historisch onderzoek naar de ontwikkeling van de huiselijke materiële cultuur van Marokkaanse migranten in Nederland, 1960-2003. Doctoraalscriptie Maatschappijgeschiedenis, Erasmus Universiteit Rotterdam. 
Domke, S. (2002) Praktikumsbericht. Praktikum am Meertens Institut Amsterdam. (Intern rapport van een stage ter voorbereiding op het project Migratie en Materiële Cultuur.)

Frijhoff, W. (1997) Toe-eigening: van bezitsdrang naar betekenisgeving. Trajecta 6 (2) 99-II 8 .

Frijhoff, W. (2003) Toe-eigening als vorm van culturele dynamiek. Volkskunde I04 (I) 3-I7.

Gandolfi, P. (2004) Moroccan migrants' uses of objects as material and symbolic meanings of cultural belongings and social status. Paper voor de 8ste SrEF/3e ADAM conferentie, Marseille.

Gans, H.J. (I962) The Urban Villagers. Group and Class in the Life of Italian-Americans. New York: The Free Press of Glencoe.

Gans, H.J. (1979) Symbolic ethnicity: the future of ethnic groups and cultures in America. Ethnic and Racial Studies 2 (I) I-20.

Gans, H.J. (I994) Symbolic ethnicity and symbolic religiosity: towards a comparison of ethnic and religious acculturation. Ethnic and Racial Studies I7 (4) 577-592.

Ger, G. en P. Østergaard (1998) Constructing Immigrant Identities in Consumption: Appearance among the Turko-Danes. Advances in Consumer Research 25, 48-52.

Gullestad, M. (I993) Home decoration as popular culture: constructing homes, gender and classes in Norway. In T. del Valle (red.) Gendered Anthropology. Londen/New York: Routledge, 128-16r.

Günter, B. (1995) Schonen-Schützen-Scheuern. Zum Wohnalltag von Arbeiterfamilien im Ruhrgebiet der zwanziger Jahre. Münster/New York; Waxmann Verlag.

Hasirci, N. (2001) Nederlandse meubels met een Turks tintje. Stagerapport Meertens Instituut Amsterdam (KNAW).

Heinze, A.R. (1990) Adapting to Abundance. Jewish Immigrants, Mass Consumption, and the Search for American Identity. New York: Columbia University Press.

Horst, H. van der \& Jantine Messing (2003) 'Bij Marokkanen zijn de gordijnen dicht.' Agora 19 (4) I4-16.

Horst, H. van der (2005a) 'Turkish' lace in a variety of contexts; constructing modernity and authenticity in the ethnic field. (draft)

Horst, H. van der (2005b) The material and meanings in a plural society; the material and the social positioning of Turkish migrants in the Netherlands. 19th months paper for the Amsterdam School for Social Science Research.

Horst, H. van der Horst (2005c) Living Amsterdam, tangible homes behind Amsterdam's facades. (draft)

Joy, A. e.a. (1993) The Cultural Past in the Present: The Meaning of Home and Objects in the Homes of Working-Class Italian Immigrants in Montreal. In: Marketing in a multicultura world: Ethnicity, nationalism, and cultural identity. Londen: Sage Publications, I45-179.

Katschnig-Fasch, E. (1998) Möblierter Sinn. Städtische Wohn- und Lebensstile. Wien/Köln/ Weimar: Böhlau Verlag.

Kilickiran, D. (2002) Migrant Homes. Negotiation of Migrant Identities in Domestic Space. http://espadom.persigeo.cnrs.fr/Intra/Kilickiran.nl. NB: In het frans verschenen als: Kilickiran, D. (2003) Féminisme et sens de l'espace domestique des femmes déplacées. Les réfugiées Kurdes à Londres dans leurs appartements. In: B. Colligingon \& J.F.-Staszak (red.) Espaces domestiques: construire, habiter, représenter. Rosny-sous-bois: Bréal, 354-396.

Leatemia, L. (1992) Het interieur als spiegel van de Molukse identiteit. Een onderzoek naar de relatie tussen hedendaagse materiële cultuur en de identiteit van Molukkers in Nederland. Doctoraalscriptie Culturele Antropologie/ niet-Westerse Sociologie, Universiteit van Amsterdam.

Masharawi, R. (I998) Dagboek van een verblijf in Lombok. Amsterdam: De Balie, destijds te lezen op de internetsite http://www.balie.nl/dagboek/rashid.html.

Messing, J. (2005) De interieurs van Hindostaanse Surinamers en hun nakomelingen in Nederland. rgde maands paper voor de AssR. (draft)
Metha R. en R.W. Belk (199I) Artifacts, Identity, and Transition: Favorite Possessions of Indians and Indian Immigrants to the United States. Joumal of Consumer Research I7, 398-4II.

Meulendijks, J. (2004) Herkomst in Huis. De reflectie van etniciteit in de materiële wooncultuur van driegeneraties Indische Nederlanders. Doctoraalscriptie Geschiedenis, Erasmus Universiteit Rotterdam.

Miller, D. (I994) Modernity. An Ethnographic Approach. Dualism and Mass Consumption in Trinidad. Oxford: Berg Publishers.

Pallowski, K. (I99r) Sozialer Fortschritt, aber Geschmackskatastrophe? Interpretationsmuster für Arbeiterwohnungen in der BRD. In: W. Kaschuba, G. Korff en B. Jürgen Warneken (red.) Arbeiterkultur seit 1945-Ende oder Veränderung? Tübingen: Tübinger Vereinigung für Volkskunde, I68-187.

Poot, G. (2004) Suriname in huis. Verslag van een onderzoek naar de interieurs van Creoolse Surinamers in Nederland. Stageverslag UvH/siswo.

Roth, K. (1999) Zur Sache! Materielle Kultur und interkulturelle Kommunikation. In: Netzwerk Volkskunde. Ideen und Wege. Wenen: Verein für Volkskunde, 3I7-335.

Salih, R. (2002) Shifting meanings of 'Home'. Consumption and identity in Moroccan women's transnational practices between Italy and Morocco. In: N. Al-Ali en Kh. Koser, New Approaches to Migration? Transnational communities and the transformation of home. London/New York: Routledge, 5I-67.

Schrover, M. (r999) Wie zijn wij? Vrouwen, eten en etniciteit. In: Voeden en Opvoeden. Jaarboek voor vrouwengeschiedenis I9, II5-I44.

Secondulfo, D. (1997) The Social Meaning of Things. A Working field for Visual Sociology. In: Visual Sociology I2 (2) 33-45. 